\title{
Interactive comment on "Modal sensitivity of rock glaciers to elastic changes from spectral seismic noise monitoring and modeling" by Antoine Guillemot et al.
}

\section{Anonymous Referee \#2}

Received and published: 25 September 2020

Please find the review attached

Please also note the supplement to this comment:

https://tc.copernicus.org/preprints/tc-2020-195/tc-2020-195-RC2-supplement.pdf

Interactive comment on The Cryosphere Discuss., https://doi.org/10.5194/tc-2020-195, 2020. 